\title{
Exploring Sustainability Reports in The Indonesian Palm Oil Industry
}

\author{
Nurhayati Soleha ${ }^{1 *}$, Rita Rosiana ${ }^{2}$ \\ ${ }^{*}, 2$ University of Sultan Ageng Tirtayasa, Indonesia \\ Corresponding Author: nurhayatisoleha@untirta.ac.id ${ }^{1^{*}}$ )
}

Keywords: sustainability report, GRI, palm oil industry

\begin{abstract}
:
The purpose of this study is to assess the quality and maturity of sustainability reports of palm oil companies listed on the Indonesia Stock Exchange (IDX). The findings indicate that there are few differences in the maturity levels of palm oil companies in implementing sustainability reporting based on GRI standards and the maturity sustainability reporting at a moderate level of relevant information. The majority of disclosure of sustainability reports is general disclosures and less present in economic and environmental disclosures. Companies need to improve the quality of their sustainability reporting and strengthen the validity of the measurement. Sustainability reports have the potential to improve the sustainability agenda by allowing management and shareholders to make more informed decisions about sustainability initiatives.
\end{abstract}




\section{Introduction}

Palm oil production is a long-lived cultivated commercial crop from which crude palm oil (CPO), palm kernel (PK), and palm kernel oil (PKO) are extracted. The derivative products are used as raw materials in food, cosmetics, pharmacy, and bioenergy. Palm oil has risen to become the world's most produced and consumed ${ }^{1}$ vegetable oil, accounting for more than a third of global vegetable oil production. This product reinforces the economies of Southeast Asian countries, particularly Indonesia, which provides 58 percent of global palm oil production, and Malaysia, which accounts for 26 percent ${ }^{2}$.

In the last two decades, the area of oil palm plantations in Indonesia has tended to increase. In 2017, the area is around 12.3 million hectares. Conversely, in the expansion of oil palm plantations, it is always associated with tropical deforestation, biodiversity damage, and obscurity of local community rights of land (Pye, 2018; White et al, 2018; Corciolani et al, 2019; Rietberg and Hospes, 2018). Because there were negative impacts on its industry that caused pressure from stakeholder groups to demand sustainable products. The company undertaken sustainability management and non-financial disclosures as commitment and communication with stakeholders caused by sustainability issues (Adams and Frost, 2008).

Many studies investigated the palm oil industry, but generally related with agricultural sciences, and chemistry, and chemical engineering and little attention on social or business, particularly on social or business were related to legitimacy and sustainability issues (Corciolani et al. 2019; Hansen et al. 2015). Corciolani et al. (2019) found around 6\% of studies related to social sciences or business, while Hansen et al. (2015) showed 95 articles related to socialeconomic from 2004-2012 and most publication frequency is policy perspective, food security, and stakeholder planning models. However, present scholars examined economic, social, and environmental disclosure on palm oil industry has been seen. Sugino et al (2015) showed six companies disclosed CSR information in the annual reports and two companies conducted standalone sustainability reports and their reports were published on the company's website. Most companies place greater importance on CSR activities to reduce the risk of conflict with local communities and engage the stakeholders on CSR activities (Sugino et al., 2015; Sunarsih and Iqbal, 2015; Abdullah et al., 2017; Pramudya et al., 2016). Their studies focused on CSR activities, but there are limited studies on sustainability reports in palm oil companies.

Fifka (2013) and Ali, et al (2017) investigated articles of determinants of CSR disclosure in developed and developing countries, but limited studies on developing countries. However, the predominantly determinant is company characteristics such as company size, industry sector, profitability, and corporate governance mechanisms. In developed countries, the determinant of CSR disclosure is more concerned with specific stakeholders, such as regulators, shareholders, creditors, investors, environmentalists, and the media. In developing countries, the

\footnotetext{
${ }^{1}$ OECD-FAO Agricultural Outlook 2018-2027
}

${ }^{2}$ Index Mundi, 2021 
predominantly determinant is influenced by pressure from external stakeholders, such as international buyers, investors, and regulatory bodies. In Indonesian companies, Soleha (2019) found the high environmental impact and larger companies tend to have a positive influence on sustainability reports.

This study investigates the extent to which sustainability reports in the palm oil industry and assessment on maturity in sustainability reports and the stakeholder's process in preparing sustainability reports. The palm oil industry is chosen because the industry has a high social and environmental impact. It causes pressure from stakeholders, especially from international stakeholders, such as buyers, NGOs, and bodies, to demand more sustainability on its business. Stakeholder engagement plays an essential in relation to the quality of reports on the materiality analysis process (Torelli et al., 2019).

This paper is structured as follows. The next section is about industry context, the important things of economic and cultural from its palm oil industry and undertaking SR in industry. The third section is the literature review regarding the quality and internal process on SR. The fourth section is the research method. And in the fifth focused on content analysis and interpretation. Finally, is a conclusion section.

\section{Palm Oil Industry context}

Indonesia is the largest economy in Southeast Asian countries. In 2018, the price gross domestic product (GDP) is 1.022 trillion USD, and GDP per capita reached $\$ 3,877$ with 261 million populations ${ }^{3}$. Economic growth remained relatively stable for five years and reached 5.2 percent in 2018. The role of the palm oil industry has an important role in improving the Indonesian economy. It's due to the palm oil production contributing the majority of the Indonesian export. In 2018, the five biggest export destination countries are India (20\%), China (14.7\%), Pakistan (8\%), Bangladesh (5\%), and the USA (4\%). Furthermore, the agriculture, forestry, and fishery sectors supply jobs to approximately $30 \%$ of the total labor force (BPS, 2019).

The total area of palm oil plantations in Indonesia is around 12.3 million hectares in 2017. State-owned enterprises play a very modest role in the Indonesian palm oil sector as they own relatively few plantations (5.20 percent). Meanwhile, big private enterprises are considered as much as 49.19 percent of total Indonesian palm oil output. Smallholder farmers account for around 45.61 percent of total production.

In contrast to giving a positive contribution to the economy, the palm oil industry is usually associated with negative environmental impacts in its operation (clearing with deforestation, greenhouse emissions, and destruction of carbon-rich peatlands). However, currently, more international companies are seeking to purchase sustainable palm oil, i.e. that meets the criteria of sustainability certification such as Roundtable on Sustainable Palm Oil

\footnotetext{
${ }^{3}$ Gross domestic product in south east Asia countries according to IMF 2019
} 
(RSPO). In 2011, the Indonesian government issued a regulation of Indonesian Sustainable Palm Oil (ISPO) which aims to enhance the global competitiveness of Indonesian palm oil and brings it under stricter environmental legislation. Certification of sustainability is the tool most used to fulfill policies that their products are sustainable and minimalize the negative social and environmental impact linked with palm oil productions.

The palm oil industry has high social and environmental impacts on its business. To communicate to stakeholders that companies have carried out sustainable activities for social and environmental in their operations, companies disclosed social and environmental activities in their standalone sustainability report, annual report, and/or companies' website. According to the palm oil companies listed on IDX in the agriculture sector, six companies (out of fourteen) have prepared standalone SRs for 2018 based on GRI. Others companies disclosed their social and environmental information on the annual report and/or companies' website.

The practice of sustainability reporting in Indonesia, relatively new, including in palm oil companies. However, the Indonesian Government has been formally regulating the corporate social responsibility practices and reporting by Law in 2007 and regulation in 2012 of Limited Liability Company which states that the company shall be obliged to perform its social and environmental responsibilities and report their social and environmental impacts in the annual report or separately. Nasution (2014) examined 50 companies listed on IDX in 2011 excluding the financial industry and discovered that 32 percent (16 companies) published SR based on GRI and while the remaining companies did not use standalone reports. In addition, Anggraeni and Djakman (2017) observed companies listed on IDX in 2014 that found 8 percent of them, or 43 out of 498 , released standalone sustainability reports.

Table 1. Corporate Sustainability Report 2018

\begin{tabular}{|c|c|c|c|c|}
\hline No. & Company & Abbr. & Lang* & $\begin{array}{c}\text { The } \\
\text { number } \\
\text { of pages }\end{array}$ \\
\hline \multicolumn{5}{|c|}{ Based on GRI standards } \\
\hline 1. & Agro Astra Lestari & AAL & $E \& I$ & 136 \\
\hline 2. & Salim Ivomas Pratama & SIP & E \& I & 118 \\
\hline 3. & Sawit Sumbermas Sarana & SSS & $E \& I$ & 150 \\
\hline 4. & Eagle High Plantations & EHP & E \& I & 110 \\
\hline 5. & London Sumatra Indonesia & LSI & $E \& I$ & 94 \\
\hline 6. & Austindo Nusantara Jaya & ANJ & $E \& I$ & 100 \\
\hline \multicolumn{5}{|c|}{ Disclosed Environmental and Social on Annual Report } \\
\hline 7. & Bakrie Sumatera Plantation & BSP & $\mathrm{E} \& \mathrm{I}$ & 29 \\
\hline 8. & Provident Agro & PA & $E \& I$ & 8 \\
\hline 9. & Sampoerna Agro & SA & $E \& I$ & 28 \\
\hline 10. & Sinar Mas Agro Resources and Tech. & SMA & $E \& I$ & 22 \\
\hline 11. & Tunas Baru Lampung & TBL & $E \& I$ & 18 \\
\hline 12. & Dharma Satya Nusantara & DSN & $E \& I$ & 15 \\
\hline 13. & Gozco Plantations & GO & $E \& I$ & 3 \\
\hline 14. & Jaya Agra Wattie & JAW & E \& I & 4 \\
\hline
\end{tabular}

*Language: E=English, I=Indonesia

Source: by the authors based on SR and AR 2018 
Companies released SR as a form of accountability and commitment management in order to present information transparently and accountability to stakeholders, as well as to accomplish the Sustainable Development Goals (SDGs) and the Environmental, Social, and Governance (ESG) principles. Furthermore, as compliance with regulation government, namely The Financial Services Authority (OJK) regulation year 2017 mentioned that the Sustainability Report for listed companies is one of the measurement tools for external stakeholders (such as banks) to conduct benchmark tests and means for banks to get feedback from stakeholders.

Sustainability Report (SR) represents a form by companies to meet their social and ethical responsibilities toward the environment and the communities and management commitment to improving social and environmental performance (Bebbington 2009; Higgins, et al, 2018). SR is an element of assessment and communication, has become an important part of companies' contribution sustainability (Lozano, et al., 2016). Whilst, The Global Reporting Initiative (GRI) stated SR is "an organization's practice of reporting publicly on its economic, environmental, and/or social impacts, and hence its contributions - positive or negative - towards the goal of sustainable development" (GRI Standards, 2016). SR based on GRI Standards is one of the forms of standalone sustainability reporting that is usually, not always a voluntary disclosure (Lozano, et al., 2016, Thorne, et al., 2014).

Many studies observed SR in high environmental impact firms such as mining, oil and gas, chemicals, and agriculture industries, seeking to adopt different initiatives to manage and report environmental impacts. Those companies report high-quality SR because they are more directly concerned with environmental and social issues (Dobbs and Staden, 2016, Martinez-Ferrero, et al., 2013, Amran, et al., 2013, Higgins, et al., 2015). The firms issued standalone sustainability reporting primarily in response and communication to external stakeholders regarding sustainability policies and practices.

The generalized nature of sustainability reports is differing on the results and a limitation of the accuracy of the results of empirical studies which only focus on content analysis from the annual reports or standalone sustainability reports. Some studies attempted the social and environmental disclosures at incorporated industry-specific to unclose the limitation (Guthrie et al, 2008; Shnayder et al, 2016). Guthrie et al. (2008) investigated the social and environmental performance related to industry issues in the Australian food industry. According to their study, sustainability reporting approaches differ significantly between each company, and most disclosures were declarative in style. Companies disclosed their social and environmental performance in the annual report and on their website. Furthermore, the frequency of disclosure on a company's website was higher than annual reports. While Shnayder et al. (2016) focused on motivation for different dimensions of Corporate Social Responsibility (CSR) among sixteen package food firms. The results found the motivation from external pressures such as social pressures, and the different types of institutional and stakeholder motivate different types of CSR. Mio (2010) investigated the factors that influence the quality of sustainability reports and 
the maturity levels of sustainability report practices in Italian listed multi-utility companies. According to his study, strategic motivation has been identified as a discriminatory factor in the quality of reports, particularly in large companies. Regarding the maturity level of sustainability reports, he found a certain lack of practices on the principles of materiality and inclusiveness of stakeholders. Perez and Sanchez (2009) assessed the evolution of sustainability reporting in four companies in the mining sector with 31 sustainability reports. Their results showed that categories of accessibility and assurance, as well as economic performance, featured the lowest scores, whereas categories of context and commitment, as well as social performance, had the highest results, while categories of the environmental performance featured constant evolution, not having the biggest score. The high scores of most reports analyzed showed a good level of transparency and maturity of reporting practice (Perez and Sanchez, 2009).

Few studies investigated on social and environmental impact of its company activities in the palm oil industry. As Sugino et al. (2015) studied the driving forces of CSR activities in palm oil companies in Indonesia. They found the large company and the relationship of local communities are major driving forces on CSR activities. Abdullah et al. (2017) studied CSR engagement in the Malaysian palm oil industry. They interviewed local communities and employees. They found the important role of employees, communities, and government influence on CSR activities. They focused on CSR activities but were limited to the quality of sustainability reports in the palm oil industry. This requires a study of more in-depth sustainability reports in increasing transparency and accountability of companies to stakeholders.

From the literature review, we have found limited empirical studies in the quality sustainability reporting in industry-specific in developing countries, particularly in the palm oil industry. To address this gap, we attempt to investigate sustainability reports in the Indonesian palm oil companies. This paper applied content analysis to assess the extent of the quality sustainability reports and the internal process on sustainability reports. The quality of sustainability reports could be shown a good level of transparency and maturity of reporting practices and could be a driving force for decision-making for management and shareholders to be more sustainable and also for stakeholders to assess the company better.

\section{Research Method}

This research method employed content analysis to measure the extent of sustainability reports by palm oil companies. We selected the palm oil companies in developing countries, i.e., Indonesia that has global issues in their industry such as deforestation and loss of biodiversity. The negative issues on their business can impact downstream industries such as a decline in demand for palm oil. The palm oil industry sought to communicate to stakeholders that they were doing has followed sustainability both environmental and social, through issuing sustainability reports.

This study used database from the Indonesia Stock Exchange (IDX) in the agriculture sector. 
We discovered 18 companies. 16 companies (out of 18 ) that met our criteria, with palm oil as the major commodity. In June 2019, we collected sustainability reports and annual reports based on the companies website. We got six companies that conducted SR for 2018 and 14 companies that published AR 2018. Sustainability reports in the palm oil industry have been involved over recent years and which dimensions of the reports have been involved the most. This study used SR based on GRI standards for measuring the extent of sustainability reports. To assess the extent of SR, we used the latest standard of GRI, i.e., GRI standards 2016, and assess the similarity nature of reports. A basic rating scale (0 and 1 ) was used for recording the absence or presence of information and a final percentage score was obtained for each report. There is a limitation to using the content analysis, such as subjectiveness of assessment by relying on interpretations (Guthrie et al, 2008; Perez and Sanchez, 2009).

Table 2. Assessment items based on GRI standards 2016

\begin{tabular}{|c|c|c|c|c|c|}
\hline & Category & $\begin{array}{c}\text { Total } \\
\text { Indicator }\end{array}$ & & Category & $\begin{array}{c}\text { Total } \\
\text { Indicator }\end{array}$ \\
\hline 102 & General Disclosure & & 400 & Social & \\
\hline $102-1$ & Organizational profile & 13 & 401 & Employment & 3 \\
\hline $102-2$ & Strategy & 2 & 402 & Labor/Management Relations & 1 \\
\hline $102-3$ & Ethics and integrity & 2 & 403 & Occupational Health and Safety & 4 \\
\hline $102-4$ & Governance & 22 & 404 & Training and Education & 3 \\
\hline $102-5$ & Stakeholder & 5 & & & \\
\hline $102-6$ & $\begin{array}{l}\text { engagement } \\
\text { Reporting practice }\end{array}$ & 12 & & & \\
\hline 103 & $\begin{array}{l}\text { Management } \\
\text { approach }\end{array}$ & 3 & 405 & Diversity and Equal Opportunity & 2 \\
\hline 200 & Economic & & 406 & Non-discrimination & 1 \\
\hline 201 & $\begin{array}{l}\text { Economic } \\
\text { Performance }\end{array}$ & 4 & 407 & $\begin{array}{l}\text { Freedom of Association and } \\
\text { Collective Bargaining }\end{array}$ & 1 \\
\hline 202 & Market Presence & 2 & 408 & Child Labor & 1 \\
\hline 203 & $\begin{array}{l}\text { Indirect Economic } \\
\text { impacts }\end{array}$ & 2 & 409 & Forced or Compulsory Labor & 1 \\
\hline 204 & $\begin{array}{l}\text { Procurements } \\
\text { Practices }\end{array}$ & 1 & 410 & Security Practices & 1 \\
\hline 205 & Anti-corruption & 3 & 411 & Rights of Indigenous Peoples & 1 \\
\hline 206 & $\begin{array}{l}\text { Anti-competitve } \\
\text { behavior }\end{array}$ & 1 & 412 & Human Rights Assessment & 3 \\
\hline 300 & Environmental & & 413 & Local Communities & 1 \\
\hline 301 & Materials & 3 & 414 & Supplier Social Assessment & 2 \\
\hline 302 & Energy & 5 & 415 & Public Policy & 1 \\
\hline 303 & Water & 3 & 416 & Customer Health Safety & 2 \\
\hline 304 & Biodiversity & 4 & 417 & Marketing and Labeling & 3 \\
\hline 305 & Emissions & 7 & 418 & Customer Privacy & 1 \\
\hline 306 & Effluents and waste & 5 & 419 & Socioeconomic Compliance & 1 \\
\hline 307 & $\begin{array}{l}\text { Environmental } \\
\text { Compliance }\end{array}$ & 1 & & & \\
\hline
\end{tabular}




\section{Results and Discussions}

Total

136

Internal Process and Materiality Relevance on Sustainability Reports

Six companies listed on IDX published standalone sustainability reports for 2018 . There are Astra Agro Lestari (we abbreviated as AAL), Salim Ivomas Pratama (abbreviated as SIP), Sawit Sumbermas Sarasa (abbreviation is SSS), Eagle High Plantation (abbreviated as EHP), London Sumatra Indonesia (abbreviated as LSI), and Austindo Nusantara Jaya (abbreviated as ANJ). In this section, we discuss the internal process and materiality relevance of their sustainability reports.

\section{Astra Agro Lestari (AAL)}

AAL is Indonesia's largest palm oil corporation. AAL has a total of 285,000 hectares, 46 subsidiaries, and 47,218 employees as of 2018. The operational region includes the islands of Kalimantan, Sumatera, and Sulawesi. Astra International (listed on IDX) owned 79.68 percent of the company's stock, while the public held 20.32 percent. Net revenue recorded 19.08 trillion Rupiah, and CPO production reached 1.94 million tons.

The company initially released a standalone report, focusing on implementation of its Social Responsibility strategy for 2005 , which focused on the community development programs carried out by the company for nearby communities. For 2011, AAL employed the Global Reporting Initiative (GRI) standards, demonstrating the company's responsibility to stakeholders on a global scale. From 2011 to 2018, the corporation did not employ an external assurance for its Sustainability Reports.

The governance structure changed several times from 2009 to 2018, which is related to company's sustainability activities and sustainability reporting. In 2009, AAL established an Environment \& Social Responsibility (ESR) Director, which is responsible for managing the social and natural environment in the plantation areas. This director was done to improve the company's performance in social responsibility and environmental management. In 2013, ESR Director become Sustainability and Public Relation Director, which had five divisions. In 2018, the company merged the sustainability team's organization by several related departments into a single organization. President Director is responsible for the development and evaluation of Sustainability Policy, assisted by the Chief of Communication and Sustainability Officer (CCSO). In policy implementation, the Vice President of Sustainability is responsible for reporting the progress of policy implementation periodically to the President Director and CCSO. Vice President of Sustainability supervises six departments supported by around 30 employees at the head office.

The priority material topics discussed in the sustainability report for 2018 were obtained through various methods such as involvement in activities and forums, including correspondence with stakeholder groups from non-profit institutions partner technical consultants, investors, and 
customers both local and international buyers. Based on the results of review and stakeholder feedback, the company conducted an analysis and categorized sustainability topics according to the level of stakeholder concerns and their impact on the business.

The material topics of sustainability report for 2018 are traceability and supplier compliance, transparency and accountability, in the indigenous peoples, fires, peatland management, biodiversity and high conservation value (HCV) areas, and relations with stakeholders. One of the material topic in the plantation is traceability and supplier compliance. The company's commitment to responsible raw material sourcing developed a traceable and transparent supply chain in achieving a sustainable production process. Each raw material received from nucleus plantations and third-party suppliers must originate from a production process that meets the principles of AAL's sustainability policy. A mill supplying CPO \& PKO can be considered traceable if information about it is available such as company group name, company name, mill name, complete address, mill coordinates, volume received by the refinery, and any certification obtained. In 2018, Astra Agro achieved 100\% traceability to a mill with a total of 128 supplier companies.

2. Salim Ivomas Pratama (SIP)

The majority of shares are owned by Indofood Agri Resources Ltd, Singapore as 73.46 percent, while public share ownership was 19.86 percent, and Indofood Sukses Makmur was 6.6 percent. SIP has 301,721 hectares nucleus planted area. The total CPO production was 921,000 tons. Net sales recorded 14.19 trillion rupiahs.

The first sustainability report was published for 2014. A sustainability report is published annually since 2014 - 2018 in accordance with the GRI G4 guidelines (Core level). SIP has not used any third-party assurance on sustainability report. SIP Group's sustainability initiatives are championed by the Sustainability Team. The Sustainability Team works with the R\&D team to improve agronomic practices and HCV area development. The Enterprise Risk Management (ERM) Unit supported the team in matters relating to policy development, strategy formulation, and issues resolution. The Sustainability Team reports to the CEO and Sustainability Think Tank, comprising the Board members of SIP Group and its principal subsidiaries. The Sustainability Think Tank met regularly to review the progress and direction of SIP Group's sustainability management efforts. In the refineries, a Sustainability Coordinator worked closely with the factory managers to support and monitor the implementation of sustainability, environment and Occupational, Health and Safety (OHS) compliance, policies and systems. Community and smallholder programs are implemented by Solidarity and Community Development Officers in close coordination with operational teams and the human resources department.

The company identified most material sustainability issues by holding the workshop attended by senior management in June 2013. Issues were also identified and prioritized through other internal workshops, peer reviews, engagement with international NGOs, and social impact assessments at site level. Stakeholder engagement takes place throughout the year during which 
information relevant to the business and its functions were collated and processed in the materiality assessment. Management concluded that the materiality assessment and ongoing sustainability programs were relevant and on track. The materiality issues in SR for 2014 are carbon management including deforestation, environmental footprint, governance transparency, land rights, smallholders, occupational health \& safety, RSPO/ISPO, and human rights.

Deforestation is a major concern. Certification is still an important aspect of ensuring a long-term supply chain of palm oil industry. The demand for certified sustainable palm oil is on the rise. The company adheres to the RSPO's principles and criteria, which are the global sustainability benchmark for the palm oil industry. One of the RSPO's criteria is traceability which ensures that the raw materials come from sustainable sources. Markets require transparency about where palm oil originates from and the effects it has upstream. Consumers' trust in palm oil is critical to commercial success. Their purchasing patterns are also being scrutinized, and having more information can help improve transparency on food safety. The company published SR is one of the approaches of palm oil to fulfill stakeholders' interest.

\section{Sawit Sumbermas Sarana (SSS)}

The majority shareholder of SSS is owned by Citra Borneo Indah 53,75 percent, with the rest of the company owned by the public as much 36.03 percent, and Putra Borneo Agro Lestari as much as 10.22 percent. SSS reported sales of 3.71 trillion Rupiah, and CPO production is 368,153 tons with 95,770 hectares of the planted area.

The first sustainability report was published by SSS for 2016. The company used GRI G4 standards. SSS did not utilize external assurance services to control the credibility of the data reported. SR was conducted annually for 2017 - 2018. SR prepared by the Sustainability Reporting Team whose members are representatives from relevant department such as Human Resources, Finance, Environment and CSR, Health and Work Safety, Procurement of Goods and Services, Production, and Marketing Divisions. In the framework of compliance, SSS is committed to preparing sustainability reports and publishing them to stakeholders annually as required by the regulation. Furthermore, this report is an important instrument for continuous improvement in the company's sustainability performance.

The company processed for determining the content and material topics of the report is based on the regulatory compliance; the result of risk management analysis; recommendation based on the RSPO, ISPO, ISO 9001; ISO 14001; OHSAS 8001, and Corporate Performance Rating Program for Environmental Management (Indonesian abbr. PROPER) from the Ministry of Environment and Forestry. After this process, several key topics become the attention of the stakeholders, namely environment-friendly plantation practices, occupational health and safety; community development programs, and the protection of biodiversity.

4. Eagle High Plantations (EHP)

The shareholders of EHP are Rajawali Capital International (37.70 percent), FIC Properties Sdn Bhd, Malaysia (37 percent), and Public (25.3 percent). Total CPO production is 361,571 tons 
and the area plantations are 148,000 hectares. The company recorded a revenues value of much as 3.08 trillion Rupiah.

EHP published the first sustainability report for 2017. This report was composed in accordance with the Global Reporting Initiative (GRI) G4 Standards. This report has not received verification from an independent external institution. There is a significant change in a organization structure in 2017. The company has a new Sustainability Director because entering a new shareholder. The Sustainability Director participates in performing efforts for employee competence development and sustainability standards implementation socialization to all parties.

The company established material sustainability information in two categories, "very high" and "high" categories. In the very high category, the material topics are Customer Health and Safety, Economic Performance, Waste and Effluent, and Emission. Other information in the "high" category are Work Health and Safety, Biodiversity, Local Communities, and Manpower. According to the report, EHP developed risk management strategies to identify and analyze the risks caused by various external factors beyond the company's control. External factors such as social and environmental situations have an impact on palm oil pricing. Therefore, EHP established control principles by conducting social and environmental impact assessments, as well as assessments of high conservation value (HCV) on existing areas or whenever new land was opened for planting. 5. London Sumatra Indonesia (LSI)

The majority shareholders of LSI are Salim Ivomas Pratama (SIP) as much as 59.51 percent and public as much 40.38 percent, and minority shareholders as much 0.11 percent. LSI has 115,904 hectares of plantations. Total CPO production is 453.168 tons. Total sales are 4.02 trillon Rupiah.

For the first time, LSI published SR for 2017. The company published sustainability reporting in accordance with GRI standards. LSI did not use assurance external from a third party on the sustainability report. The Board of Directors (BoD) considers sustainability issues, reviews material environmental, social, and governance (ESG) topics, and oversees their management and monitoring. LSI's sustainability management is led by the President Director who updates the Board on sustainability management initiatives, performance against key ESG topics, stakeholder engagement, and response to issues arising. A Sustainability Think Tank meets regularly to review the sustainability progress and direction and comprises BoD, Chief Operating Officers, Enterprise Risk Management (ERM) unit, R\&D team, and sustainability representatives from all business units. The Audit and Risk Management Committee is updated on a quarterly basis on matters relating to material sustainability risks and concerns.

According to the report, President Director personally took part in discussions and correspondence relating to ongoing impacts in the field. Senior leaders of the sustainability team in Jakarta regularly report internally at LSI's Board level on issues such as process safety and efficiency, community investment, and certifications. Headline performance indicators are 
discussed, changes of direction are decided as appropriate, and often in consultation with other executives in the SIP Group, which is the parent company.

In sustainability report mentioned the company's sustainability policies apply to all lines of the company's operations, smallholders, and external suppliers. Key policy commitments are No deforestation, Conservation of High Conservation Value (HCV) and High Carbon Stock (HCS) areas, No planting on peatlands, No burning, and Human Rights. The sustainability report presented environmental performance such as obtaining a number of certifications in the company's subsidiaries or mills. ISPO certified plantations obtained 28 out of 40 sites and PROPER-certified mills obtained 9 out of 12 sites.

6. Austindo Nusantara Jaya (ANJ)

ANJ's majority shareholders are Austindo Kencana Jaya with 40.85 percent and Memimpin Dengan Nurani at 40.85 percent, and as well as minority shareholders are public at 7.65 percent and others 8.48 percent. Revenue was recorded at 161.7 million USD. CPO production is 210,248 tons with a total plantation area is 52,813 Hectares.

ANJ published the first SR based on GRI for 2016. ANJ did not use the assurance of SR from an independent party. In determining the material topics of SR, the company has adopted the following principles: stakeholder inclusiveness, sustainability context, materiality, and completeness. The company identified the sustainability aspects relevant to ANJ's business characteristics and determined their degree of materiality. This process has been internally carried out by conducting an internal discussion, led by Director Sustainability, a study of the social and environmental impact, and grievance reports addressed by stakeholders. The process of determining materiality topics of six aspects, namely, environmental management, local community, traceability, sustainability certification, economic performance, and occupational health and safety.

The extent of SR

A total of six sustainability reports for 2018 were examined. All sustainability reports are based on GRI standards. Each report was checked for the presence of each of the 136 items featured in Table 2 . The results are shown in Table 3.

In the first indication, general disclosure, all companies disclose more, and mostly disclosed by AAL (75 percent). Economic indicators were the lowest ratings, which SIP and LSI reveal the least. Conversely, SIP and LSI more disclose about environmental indicators (40 percent). On social indicators more disclosed by AAL and SIP. Overall, AAL and SSS provide the greatest information on corporate sustainability (54 percent). The average adoption GRI standard is 50 percent. 
Table 3. Total assessment

\begin{tabular}{clcllccc}
\hline & Assessment categories & AAL & SIP & LSI & SSS & EHP & ANJ \\
\hline \multirow{2}{*}{102} & General Disclosure & 44 & 35 & 37 & 40 & 40 & 42 \\
& compared with indicator of 102 & $75 \%$ & $59 \%$ & $63 \%$ & $68 \%$ & $68 \%$ & $71 \%$ \\
& Economic & 2 & 1 & 1 & 6 & 3 & 3 \\
& compared with indicator of 200 & $15 \%$ & $8 \%$ & $8 \%$ & $46 \%$ & $23 \%$ & $23 \%$ \\
\multirow{2}{*}{300} & Environmental & 8 & 12 & 12 & 8 & 11 & 10 \\
& compared with indicator of 300 & $27 \%$ & $40 \%$ & $40 \%$ & $27 \%$ & $37 \%$ & $33 \%$ \\
& Social & 19 & 19 & 15 & 20 & 10 & 10 \\
& compared with indicator of 400 & $56 \%$ & $56 \%$ & $44 \%$ & $59 \%$ & $29 \%$ & $29 \%$ \\
\hline \multirow{2}{*}{ Total } & 73 & 67 & 65 & 74 & 64 & 65 \\
& Tot & $54 \%$ & $49 \%$ & $48 \%$ & $54 \%$ & $47 \%$ & $48 \%$ \\
\hline
\end{tabular}

Source: by the authors based on SR 2018 matched with GRI standards 2016

Discussion

All companies published sustainability reports with over 64 item indicators (47 percent) of assessment items met. AAL and SSS presented the majority of the sustainability based on GRI standards (both are 54 percent). Although each company obtained a distinct score, the total scores are not that dissimilar. It implies placing them practically in not very different levels of maturity. According to the reports, AAL was the first company who publish a standalone social responsibility report in 2005, and in 2011 sustainability report based on GRI standards, however, compared with SSS who published the first SR for 2016, AAL and SSS almost have the same obtained item categories of GRI standards. Sustainability report based on GRI was a new experience in this industry, it seems some companies sought to follow the GRI standards. All companies did not use an external assurance for Sustainability Report 2018.

Sustainability reports are presented in two languages, English and Indonesian in a single book. Only ANJ provides in two languages that are separated by books. SR was provided in two languages for communicating with internal and external stakeholders. In addition, companies strive to meet the demands of international stakeholders in conveying their companies' sustainability performance. Furthermore, based on the composition of Board of Directors (BoD), Board of Commissioners (BoC), and shareholders some of whom are from abroad.

All companies presented general topics such as CEO statements, organizational profile and contacts, stakeholders engagement, and reporting practices. However, economic and environmental performance was the topic with less presented. Economic performance is less presented, it could be companies have prepared the financial performance in a separate annual report. Whilst, environmental indicators, some companies provide environmental information in accordance to 103 standard, but they did not mention the relationship according to the standard 300: environmental, although they have conducted reduction of Green House Gas Emissions.

The unique report in the palm oil industry seems on the 103 standard regarding management approach. The environmental impact of its business operations in the palm oil 
industry is generally associated with deforestation and the use of peatlands in the expansion of oil palm plantations. In this case, the company seems to make information regarding sustainability efforts but visibly difficulties in applying the GRI standards. They attempt to inform under standard of 103 and about environmental (300) such as no deforestation and consistent with fire prevention.

Another unique report, about material items (a 301 standard). The palm oil industry is an integrated industry from upstream to downstream industries, i.e. from plantations and refineries. Inputs applied in oil palm cultivation in the plantation are fertilizers, pesticides, and seedlings. While mills, inputs for the production process of Crude Palm Oil (CPO) are Fruit Fresh Bunches (FFB). In this case, companies provide a variety of reporting, even for the standard of 301, some companies do not have many fills. The same case is with items of standard 204 regarding procurement practices. But in general, they provide in the 102-9 standard regarding supply chains. This is also supported because it refers to requests from certification organizations namely RSPO and ISPO where there is one of the principles that are 'traceable'. For FFB raw materials come from plantations that are not open of the forestry areas or no deforestation.

Based on institutional companies in preparing sustainability reports and sustainability activities, several companies have been changed governance structures several times. Most companies have a sustainability department/division. Indeed, one company has a Board of Commissioners (BoC) that is internalized in one committee, i.e. CSR and Sustainability Committee. However, this internal process is different from sustainability reports. Not all companies institutionalize in one division or department but make coordination with several divisions to undertake a sustainability report and few companies have been compiled by a third party, that is an external consultant, who is authorized to access and use all data related to social and environmental impact. Regarding the content of the sustainability report, it was seen that the LSI report imitates the SIP report. It is unsurprisingly because these companies have a relationship, that SIP is the holding company of LSI. It showed that the holding company has an influence on the companies that are under its control, including in making sustainability reports.

\section{Conclusion}

This study explores the quality and the maturity level of sustainability reports practices in a specific industry, i.e., the palm oil industry. The palm oil industry is chosen because this industry has high social and environmental impacts on its business. To address this study, we employ a content analysis of sustainability reports based on GRI standards. The absence or presence of information is assessed using scales 0 and 1 . This method is simply applicable. It is due to the easier to obtain data from listed companies and these data can be quantified and classified easily (Fifka, 2013). However, in this study, there are limitations, such as subjective assessment based on a single rater's interpretation, and inaccurate value, where companies with detailed information and companies with incomplete information are given the same score (Guthrie et al., 2008). 
In 2018, six palm oil companies listed on IDX published sustainability reports with more than 64 item indicators (47 percent) of assessment items met, and mostly presented by AAL and SSS (both are 54 percent). It implies placing them practically in not very different levels of maturity. Although AAL is the first company who publish a standalone social responsibility report in 2005, and in 2011, sustainability report based on GRI standards, compared with SSS published the first SR for 2016, AAL and SSS almost have the same implementation of GRI standards. Six companies presented general topics such as CEO statements, organizational profile and contacts, stakeholder engagement, and reporting practices. This general information, mostly disclosed by AAL (75 percent). The lowest scores on economic indicators which are SIP and LSI reveal the least. Conversely, SIP and LSI more disclose on environmental indicators (40 percent). On social indicators more disclosed by AAL and SIP.

Another characteristic found in the research is that each company uses different approaches to disclose information. Especially, indicator 103 standard regarding management approach for environmental standard (300). In this case, the company presented information regarding sustainability efforts for environmental management, such as no deforestation and consistent with fire prevention but seems visibly to be difficult to disclose according to the GRI standards. These companies could improve further the reporting process by meeting the stakeholder expectations. The high scores of most reports analyzed showed a good level of transparency and maturity of reporting practice. Particularly, AAL is the company with the highest score, it is due to AAL being more experienced in the preparation of SR and as the largest company in the palm oil industry which listed IDX. In general, all companies published sustainability reports with a moderate level of sector-relevant information. The largest companies in the palm oil industry are clearly producing more comprehensive and more sophisticated sustainability reports. Besides, six companies disclosed sustainability in a standalone sustainability report and annual report, these companies also provide social and environmental information on their website. However, the companies need to advance their disclosure, increase the validity of the measurement, and improve the quality of their sustainability reporting to the next level. This report could be a positive role in enhancing the sustainability agenda, as well as enabling management and shareholders to make a decision making for undertaking more initiative sustainability. For future research, to explore the dynamics of the internal process in undertaking sustainability management and reporting. There are different actors, changes behaviors, and structure organizations that happened in those companies for preparing sustainability reporting and sustainability initiatives.

\section{References}

Abdullah, et al. (2017). A holistic approach to CSR engagement in palm oil industry. International Journal of Advanced and Applied Sciences, 4(12), 16-20.

Ali, W., and Frynas, J.G. (2018). The Role of Normative CSR-Promoting Institutions in Stimulating 
CSR Disclosures in Developing Countries. Corporate Social Responsibility and Environmental Management, 25(4), 373-390.

Ali, W., Frynas, JG., and Mahmood, Z. (2017). Determinants of Corporate Social Responsibility (CSR) Disclosure in Developed and Developing Countries: A Literature Review. Corporate Social Responsibility and Environmental Management, 24(4), 273-294.

Anggraeni, D.Y. and Djakman, CD. (2017). Slack resources, board's feminism, and the quality of corporate social responsibility disclosure. JAKI, 14(1).

Bebbington, J., Higgins, C., and Frame, B. (2009). Initiating sustainable development reporting: evidence from New Zealand. Accounting, Auditing \& Accountability Journal, 22(4), 588- 625.

Bhimani, A., Silvola, H., and Sivabalan, P. (2016). Voluntary Corporate Social Responsibility Reporting: A Study of Early and Late Reporter Motivations and Outcomes, Journal of Management Accounting Research, 28(2), 77-101.

BPS (Indonesian Statistic Agency). (2019). Statistik Indonesia 2019 (Statistical Yearbook of Indonesia 2019).

Corciolani, M., Gistri, G., and Pace, S. (2019). Legitimacy struggles in palm oil controversies: An institutional perspective. Journal of Cleaner Production, 212, 1117-1131

Dobbs, S. and Staden, C. (2016). Motivations for corporate social and environmental reporting: New Zealand evidence. Sustainability Accounting, Management and Policy Journal, 7(3), 449 -472 .

Fifka, M.S. (2013). Corporate Responsibility Reporting and its Determinants in Comparative Perspective -a Review of the Empirical Literature and a Meta-analysis. Business Strategy and the Environment, 22(1), 1-35.

Fogarty, T.J., and Dirsmith, M.W. (2001). Organizational Socialization as Instrument and Symbol: An Extended Institutional Theory Perspective. Human Resource Development Quarterly, 12(3).

GRI Standards. (2016). Consolidated Set of GRI Sustainability Reporting Standards.

Guthrie J., Cuganesan S., and Ward L. (2008). Industry specific social and environmental reporting: The Australian Food and Beverage Industry. Accounting Forum, 32, 1-15.

Hansen, S.B., Padfield, R., Syayuti, K., Evers, S., Zakariah, Z., \& Mastura S. (2015). Trends in Global Palm Oil Sustainability Research. Journal of Cleaner Production, 100, 140-145.

Herremans, I.M., and Nazari, J.A. (2016). Sustainability Reporting Driving Forces and Management Control Systems. Journal of Management Accounting Research, 28(2), 103124. 
Higgins, C., Milne, MJ., and Gramberg, B. (2015). The Uptake of Sustainability Reporting in Australia. Journal of Business Ethics, 129(2), 445-468.

IMF. Gross domestic product in southeast Asian countries according to IMF. https://www.imf.org/external/pubs/ft/weo/2019/01/weodata/weorept.aspx?sy=2016\&ey $=2020 \& \mathrm{scsm}=1 \& \mathrm{ssd}=1 \&$ sort=subject $\& \mathrm{ds}=. \& \mathrm{br}=1 \& \mathrm{pr} 1 . \mathrm{x}=47 \& \mathrm{pr} 1 . \mathrm{y}=14 \& \mathrm{c}=548 \% 2 \mathrm{C} 566 \% 2 \mathrm{C} 5$ 76\%2C578\%2C536\%2C582\&s=NGDPD\%2CTX RPCH\%2CLP\&grp=0\&a=\#download

Index Mundi (2021). Palm Oil Production by Country in 1000 MT. Retrieved November 16, 2021, from Palm Oil Production by Country in 1000 MT - Country Rankings (indexmundi.com)

Lozano, R., Nummert, B., and Ceulemans, Kim. (2016). Elucidating the relationship between Sustainability Reporting and Organisational Change Management for Sustainability. Journal of Cleaner Production, 125, 168-188.

Martínez-Ferrero, J and García-Sánchez, I.-M. (2017). Coercive, normative and mimetic isomorphism as determinants of the voluntary assurance of sustainability reports, International Business Review, 26, 102-118

Milne, M., \& Gray, R. (2013). (W(h)ither ecology? The triple bottom line, the global reporting initiative, and corporate sustainability reporting. Journal of Business Ethics, 118(1), 13-29.

Mio, Chiara. (2010). Corporate Social Reporting in Italian Multi-utility Companies: An Empirical Analysis. Corporate Social Responsibility and Environmental Management, 17, 247-271.

Perez, F. And Sanchez LE. (2009). Assessing the Evolution of Sustainability Reporting in the Mining Sector. Environmental Management, 43, 949-961.

Pramudya EP., Hospes, O., and Termeer. (2016). Governing the palm oil sector through finance: the changing roles of the Indonesian state. Bulletin of Indonesian Economical Studies, 53(1), 57-82.

Pye, Olive. (2018). Commodifying sustainability: Development, nature and politics in the palm oil industry. World Development, 121, 128-228.

Rietberg, PI., and Hospes, O. (2018). Unpacking land acquisition at the oil palm frontier: Obscuring customary rights and local authority in West Kalimantan, Indonesia. Asia Pacific Viewpoint. 59(3), 338-348.

Shnayder, L., Rijnsoever, FJ., and Hekkert, MP. (2016). Motivations for Corporate Social Responsibility in the packaged food industry: an institutional and stakeholder management perspective. Journal of Cleaner Production, 122, 212-227.

Soleha, Nurhayati. (2019). Which factors influence sustainability reporting in Indonesia? A literature review. Japanese Management and International Studies, 16,167-186 
Sugino, T., Mayrowani, H., and Kobayashi, H. (2015). Determinant International for CSR in Developing Countries: The Case of Indonesian Palm Oil Companies. Japan J. Rural Economic, $17,18-34$.

Sunarsih, U., and Iqbal, A.M. (2015). Partnership Scheme Analysis on Plasma Plantation as a Corporate Social Resposibility (CSR) Program in Oil Palm Plantation. European Journal of Business and Management, 7(4), 214-313.

Thorne, L., Mahoney, LS., and Manetti, G. (2014). Motivations for issuing standalone CSR reports: a survey of Canadian firms, Accounting, Auditing \& Accountability Journal, 27(4), $686-714$.

Torelli, R., BalluchiF., and Furlotti, K. (2019). The materiality assessment and stakeholder engagement: A content analysis of sustainability reports. Corporate Social Responsibility Environmental, 27(2), 470-484.

White, JL., and Knight, AT. (2018). Palm oil supply chain complexity impedes implementation of corporate no-deforestation commitments. Global Environmental Change, 50, 303-313. 